\title{
PRIMITIVISME IKAN POLYPTERUS SEBAGAI WARISAN MANUSIA MODERN
}

\author{
Media Fitri Isma Nugraha \\ Balai Riset Budidaya Ikan Hias \\ Jl. Perikanan No. 13, Pancoran Mas, Depok \\ E-mail: media.fitri@dkp.go.id
}

\begin{abstract}
ABSTRAK
Tinjauan ini mensintesa historis dan diversitas ikan purba Polypterus yang berasal dari Afrika sebagai komoditi budidaya ikan hias. Sejarah evolusinya sangat unik, muncul sejak pertengahan Miocen (10 juta tahun), hubungan parentalnya berada pada posisi transisional sister-takson antara Teleostei dan Tetrapoda. Primitivismenya menyisakan divergensi momental sains hampir satu abad dalam determinasi dimorfisme seksualnya. Bersifat nokturnal, tahan terhadap kondisi habitat ekstrim tetapi mudah dibudidayakan. Polypterus jantan memiliki sirip anal tebal dan condong ke hipural konjungsi sirip ekor. Seekor betina mampu bertelur 100-300 butir dan menetas kurang dari 3 hari. Benih Polypterus sudah dapat beradaptasi dengan pakan tambahan sekitar 10 hari pasca menetas, dan dalam perkembangan gonad jantan dan betina akan terbentuk sempurna setelah berumur 10 bulan. Fosil hidup Polypterus telah menjadi warisan dunia, adopsi dan asuhan penggemarnya tersebar ke-5 benua, dapat dilaporkan bahwa harga per ekor dipatok variatif antara US\$40-US\$70. Kegemaran kita membudidayakannya, berarti telah menyelamatkan populasi ikan ini agar terhindar dari kepunahan. Atas dasar konsesi dan semangat terhadap warisan spesies dunia itu, BRBIH Depok telah mengoleksi dan sukses memproduksi satu sub spesies, satu varian intergenetik-albino dari populasi Polypterus senegalus senegalus dan 3 spesies intragenerik lainnya.
\end{abstract}

KATA KUNCl: ikan purba Polypterus, primitivisme, budidaya, konservasi

\section{PENDAHULUAN}

Genus Polypterus adalah satu dari takson famili Polypteridae; Actinopterygii. Di tanah air dikenal dengan nama umum ikan "Palmas" sedangkan panggilan interkomunalnya disebut "Bichir". Di daratan Afrika, ikan ini menyandang nomenklatur sangat variatif tergantung dari mana asal spesies originalnya. Fosil hidup Polypterus dikenal di dunia sebagai buah hasil ekspedisi fenomenal ke daratan Mesir dan daratan medium Afrika yang diprakarsai oleh Napoleon Bonaparte (Gillispie, 1989). Dalam ekspedisinya mencari daratan kolonisasi, Raja Napoleon selalu membawa gloria biologis ternama pada zamannya, yaitu Geoffroy dan Hillarie dari Museum Naturelle d'Histoire dan Academie Royale des Sciences (Fessy, 1998). Tujuan pendampingan selama ekspedisi ekspansial Perancis tersebut, untuk mengkarakterisasi dan mengoleksi diversitas biotop yang ditemuinya.

Distribusi spesiesnya sangat luas dengan sentrum diversitas tepat di jantung Benua Afrika (Roberts, 1975; Otero et al., 2006). Spesies-spesies Polypterus terkenal kanibalisme, dan memakan insekta air, dan katak kecil. Di sisi lain, Polypterus sangat resisten dengan perubahan habitat, dan mampu bertahan hidup pada kondisi air yang ekstrim. Resistensi ini beralasan karena dibalut karakter morfologi yang keras-kuat di mana evolusi adaptatifnya jauh lebih tua dibandingkan dengan takson teleostei lainnya (Gosse, 1990).

Tubuh Polypterus memanjang lonjong yang diakhiri dengan fluks ekor warna krem. Bagian posterior caudal ikan ini tergolong diphycercal (tipe caudal similar dengan Coelacanth) seperti pada kebanyakan spesies ikan purba yang masih tersisa (Britz, 2004). Dalam dekade terakhir semua spesies Polypterus sudah dapat didomestikasi dan dikembangkan menjadi ikan hias. Toleransinya pada multi-habitat, kontur-postural badan yang unik, dimorfisme, dan tingkah laku lainnya dalam akuarium menjadi sederetan kalkulasi menarik bagi penggemar ikan hias di lima benua. Kegembiraan para penggemar ikan hiaspun membumbung karena pada kesimpulannya ikan ini sangat mudah dibudidayakan. Selain karena maksud "menggemari" dan sebagai asuhan pada domain akuaria, manusia modern sesungguhnya secara tidak langsung telah mereservasi spesies primitif untuk sebuah keberlangsungan warisan dunia.

\section{DISTRIBUSI SPESIES}

Daratan tertua se-planet "Afrika" dialiri ribuan ekosistem riverin (sungai), baik sungai besar dan kecil hingga perairan semi-lentik. Ekosistem akuatik yang kaya 
nutrisi di bagian tengah Afrika adalah rumah bagi 17 spesies taksa Polypterus (Roberts, 1975). Distribusi spesiesnya hampir merata di Afrika tengah, ekspansinya berlangsung di bawah skenario isolasi fragmen habitat "Allopatrik" sejak pertengahan Miosen (10 juta tahun lalu). Pada bagian timur Afrika, dihuni dua spesies (P. bichir dan P. endlicheri). Di bagian tengah Afrika, Sungai Zaire, sains mencatat fenomena isolasi spesies secara "Simpatrik" yang didiami oleh 7 spesies dan 3 sub spesies (P. endlicheri, P. congicus, P. ornatipinis, P. delhenzi, P. palmas, P. retropinis, dan P. poli). Masih di daratan tengah Afrika, sungai-sungai besar di region Katanga dihuni tiga spesies yang diduga sebagai spesies sinonimous karena tingginya plastisitas fenotipiknya yaitu P. ornatipinis, P. bichir, dan P. weeksii. Bagian barat Afrika, tepatnya di Nigeria, takson ini mendiami beberapa ekosistem riverin dan lakustrin dengan distribusi 5 spesies (P. endlicheri, P. bichir lapradei, P. endlicheri, P. senegalus (Hanssens et al., 1995; Brunet, 2000), kawasan ini pula menjadi habitat yang baik bagi satu spesies sister-intergenerik Erpetrichthys calabaricus (Kodera et al., 1992) Referensi ilmiah teraktual melaporkan bahwa Polypterus masih menyisakan perdebatan krusial di kalangan masyarakat ilmiah, karena posisi jejak relasi-evolusinya jauh lebih tua dibandingkan dengan tetua Teleostei lainnya (Gallo, 2004; Rocco et al., 2004; Noack et al., 2006; Suzuki et al., 2010).

\section{HABITAT DAN TINGKAH LAKU}

Pada observasi ekologi dan habitatnya, spesiesspesies Polypterus umumnya ditemukan di perairan aliran lambat, rawa genangan, tepian sungai, dan danau-danau semi tertutup yang dominan ditumbuhi vegetasi akuatik (Poully, 1993; Reichard, 2008). Di habitat aslinya, "Palmas" hidup di dasar sungai yang sedikit keruh dan dangkal sebagai salah satu faktor pendukung predasi. Secara glo bal menyukai perairan dengan temperatur ekuatorial antara $25^{\circ} \mathrm{C}-28^{\circ} \mathrm{C}$ dengan $\mathrm{pH}$ netral hingga sedikit asam (Hanssens et al., 1995).

Spesiesnya sangat toleran terhadap kualitas air dan temperatur yang rendah, toleransi ini diduga kuat karena proses adaptasi-evolusinya yang kuat sejak pertengahan Miosen (Britz, 2004). Parameter lain, Patterson (1982) melaporkan bahwa umumnya Polypterus bersifat nokturnal, di mana aktivitas predasinya dilakukan pada malam hari. Ikan ini sangat gesit mencari makan, dan mampu menghabiskan satu malam hanya untuk mencari makan; berenang di dasar dan sesekali kepermukaan untuk respirasi. Polypterus bersifat kanibal, tetapi cenderung memangsa ikan-ikan kecil, serangga air, dan mini-amfibia. Joe (2004) mendokumentasikan tingkah laku ini dalam beberapa kondisi, dan melaporkan bahwa Polypterus lebih dominan berenang dan berjalan di dasar daripada permukaan air. Kemampuan adaptatif ini beralasan karena memiliki sirip dada dan sirip anal yang keras berbentuk lobus dan mampu menopang seluruh bobot badannya. Hal yang similar juga didemonstrasikan oleh sederetan ikan purba lainnya, seperti Lungfish dan Coelacanth.

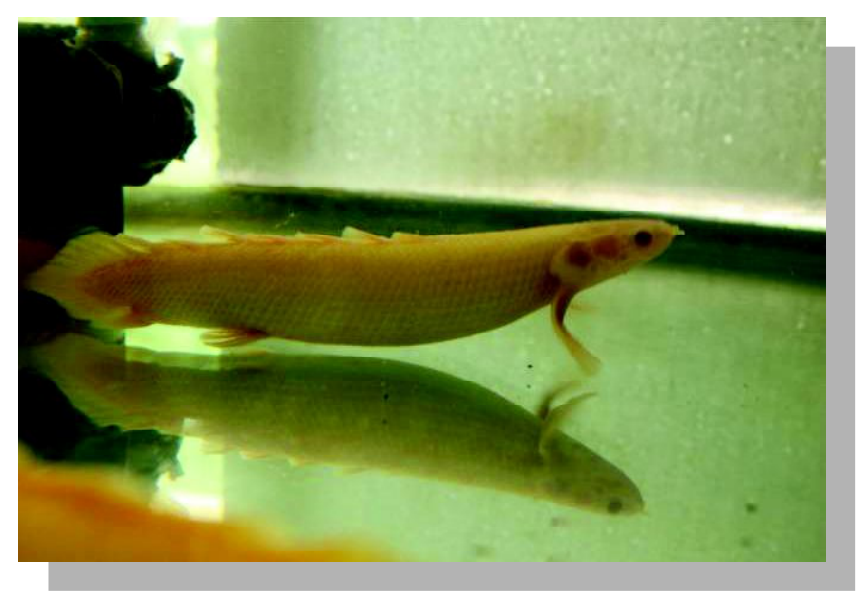

Gambar 1. Posisi ikan Polypterus saat berjalan di dasar akuarium (foto@Nugraha, 2009)

\section{SISTEM RESPIRASI}

Sistem pernafasan dan penyerapan $\mathrm{O}_{2}$ pada Polypterus ada dua tahap yaitu pertama, sistem respirasi normal; yang kedua adalah sistem alternasi dengan menggunakan gas pada paru-parunya. Kedua sistem ini menjamin Polypterus mampu bertahan lama di dasar habitatnya baik pada perairan minor-oksigen hingga perairan setengah kering (Palomares et al., 2003). Tingkat konsumsi oksigennya tergantung dari pola aktivitas, umur ikan, dan ketersediaan oksigen itu sendiri (Babiker, 1984). Paruparu pada ikan ini sangat fenomenal karena diperkaya kolesterol dan mampu menghasilkan beberapa turunan posfolipida yang jauh lebih tinggi sampai tiga kali lipat dibandingkan dengan hewan menyusui di daratan. Smith (1994) melaporkan bahwa petukaran gas $\mathrm{O}_{2}$ di dalam paru-paru pada ikan primitif sama dengan paru-paru pada hewan bertulang belakang.

\section{SPESIES KOLEKSI DAN FITUR MORFOLOGIS}

Saat ini, Balai Riset Budidaya Ikan Hias (BRBIH) Depok telah mengoleksi 4 jenis Polypterus, satu sub spesies $P$. senegalus senegalus, 3 spesies intragenerik dan satu strain albino-interbreeding P. senegalus.

Kemolekan fenotipik Polypterus dibalut dengan sisik tebal-keras, seperti pada kebanyakan spesies ikan 

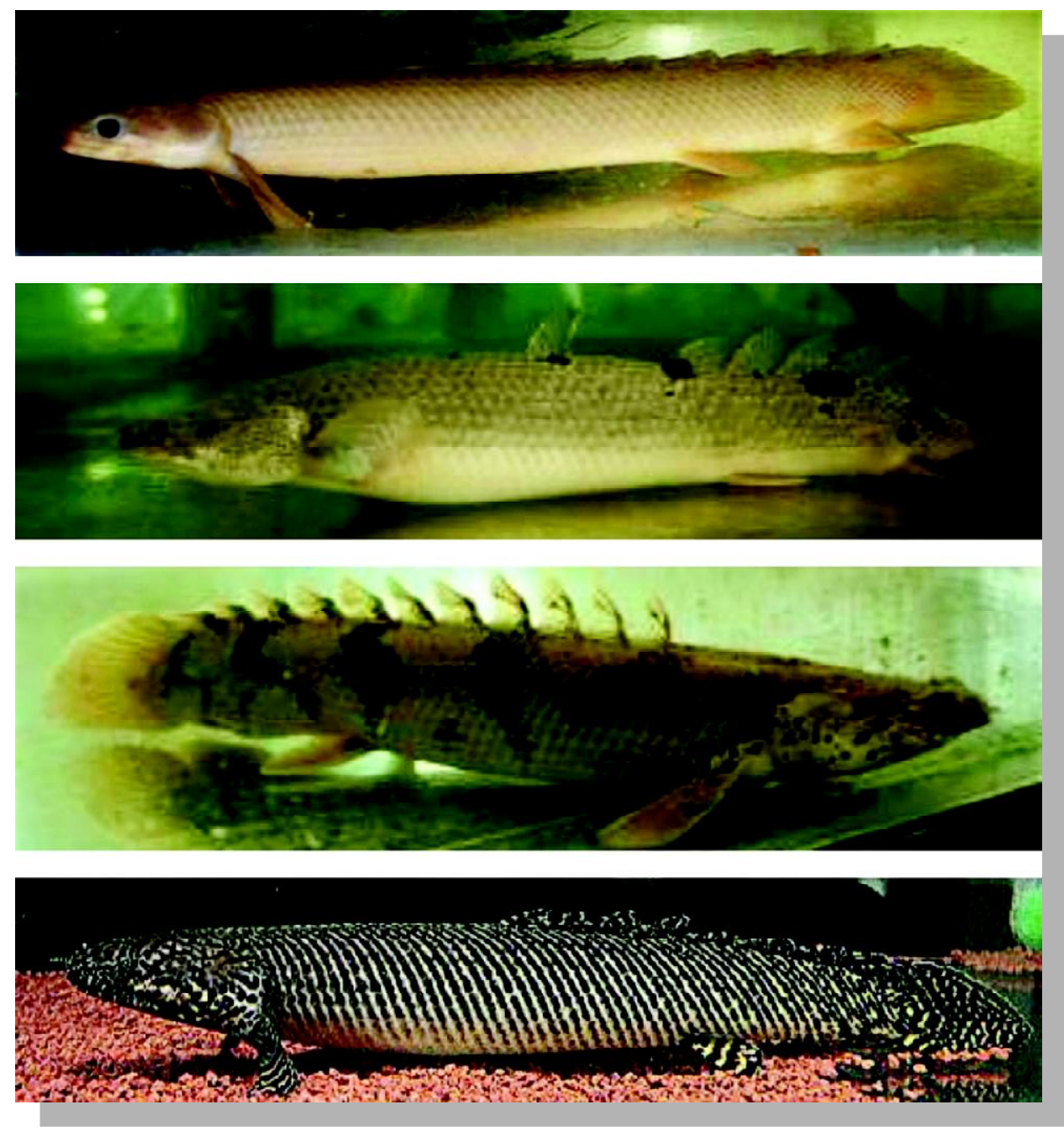

Gambar 2. Ragam spesies genera Polypterus, koleksi BRBIH, berturut-turut dari atas ke bawah (a) P. senegalus senegalus, (b) P. delhezy, (c) P. ansorgii, (d) P. ornatipinnis (foto "a-c" $\mathrm{C}$ Nugraha, 2009; foto credit " $\mathrm{d}$ " $\odot$ Josh/ivefishdirect, 2010)

prasejarah, di mana dominansi siripnya lebih banyak ditemukan di bagian dorsal. Selain itu, topologi tiap siripnya dipertegas dengan jarak selaput keras yang tahan terhadap kondisi fragmentasi habitatnya. Sisik ikan ini tergolong "ganoid" yang menyerupai bentuk "kosmoik" yang tertanam kuat dan sangat keras. Sisiksisik ganoid adalah sisik yang ditemukan pada ikan-ikan famili Lepisosteidae dan Polypteridae. Sisik berbentuk ketupat, mengkilap, dan keras. Deretan sisik keras-kuat tersebut menjadi pelindung yang baik bagi permukaan dagingnya dari ektrusi cairan tubuh akibat tekanan dan kualitas lingkungannya. Beberapa sumber melaporkan bahwa Polypterus mampu bertahan di luar habitat normalnya tanpa air hingga 2 hari, karena bagian dalam tubuhnya dilindungi sisik ganoid ini (Britz, 2004; Hanssens et al., 1995).

\section{DETERMINASI SEKS (KELAMIN)}

Primitivisme Polypterus mengukirkan sejarah panjang tentang diferensiasi gender seksualnya. Boulenger (1907) memberikan hipotesa besar bahwa kemungkinan besar jenis kelamin Polypterus dapat dikenali dari tipe postur sirip anal. Sayangnya, studi dimorfisme seksual ikan ini stagnan hampir satu abad lamanya. Sekitar 86 tahun kemudian, Komagata et al. (1993) melangsir hasil risetnya bahwa karakter morfologi penanda diferensiasi seks dapat dilihat dari penampilan jumlah sirip analnya, formasi tulang dorsal dan tingkat kehalusan dari tiap struktur sisik lateralisnya. Ikan palmas jantan pada populasi senegal (Polypterus senegallus) memiliki basal sirip anal yang tebal dan lebar yang memungkinkan tingginya probabilitas ditumbuhi jumlah jari sirip anal yang jauh lebih banyak daripada betina (Gambar 3). Posisi tulang basal sirip anal 

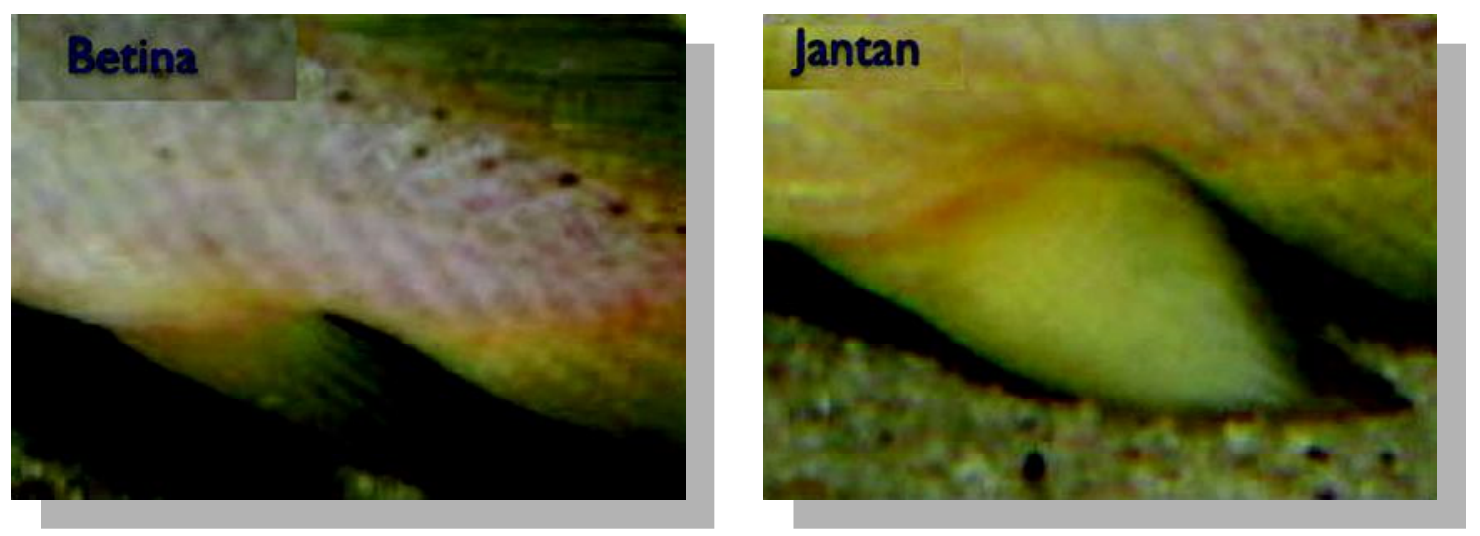

Gambar 3. Diferensiasi kelamin berdasarkan fitur karakter sirip anal genera Polypterus (foto credit@fishkeeping/adaptif Polypterus.info, 2009)

bagi palmas jantan cenderung ke bagian posterior mendekati hipural kunjungsif (pangkal/basal) sirip ekornya, sedangkan palmas betina cenderung ke interior abdomental dan menjauhi basal hipural sirip ekor.

\section{SISTEM REPRODUKSI}

Tingkah laku reproduksi dapat dilihat pada jantan dan betina yang sudah matang gonad, dengan fitur berenang berduaan, proses saling kenal dan peningkatan eksresi hormonal berlangsung sekitar 3-7 hari. Tingkah laku yang paling menonjol adalah ekpresi dua moncong kepalanya yang saling bersinggungan satu sama lain, seiring dengan waktu yang relatif singkat, pasangan tersebut mulai mencari tempat yang terisolasi dan redup dari pencahayaan. Di alam, Polypterus menggunakan tumbuhan perdu akuatik sebagai peraduan yang baik untuk memijah. Pengalaman empiris penulis, bahwa wadah peraduannya dapat dimodifikasi sesuai dengan ketersediaan bahan lokal, seperti utasan-jumbai tali rafia yang dibentuk seperti pakis air.

Setelah betina melepaskan telur-telurnya, diikuti sang jantan mengekstrusi dengan spermanya, kondisi inilah puncak ereksi seks keduanya sebagai tanda lahirnya generasi baru. Seekor betina Polypterus dapat menghasilkan 100-300 butir telur. Untuk mengurangi kanibalisme, sesaat setelah telur-telur dilepaskan oleh betina dan pasca pembuahan ovum, segera mungkin kedua induknya dipisahkan atau ditransfer ke bak lainnya. Telur-telur akan menempel pada jumbai rafia dan akan menetas dalam waktu 3 hari (Subamia et al., 2008). Telurtelur Polypterus memiliki bentuk morfologi yang unik dibandingkan dengan teleostei lainnya. Ukuran telurnya rata-rata $25 \mu \mathrm{m}$ dan memiliki dua buah kutub hitam-putih, kontraksi pembelahan ovunal sangat stabil dan sempurna, ciri identitas spesies-spesies primitif. Selain itu,

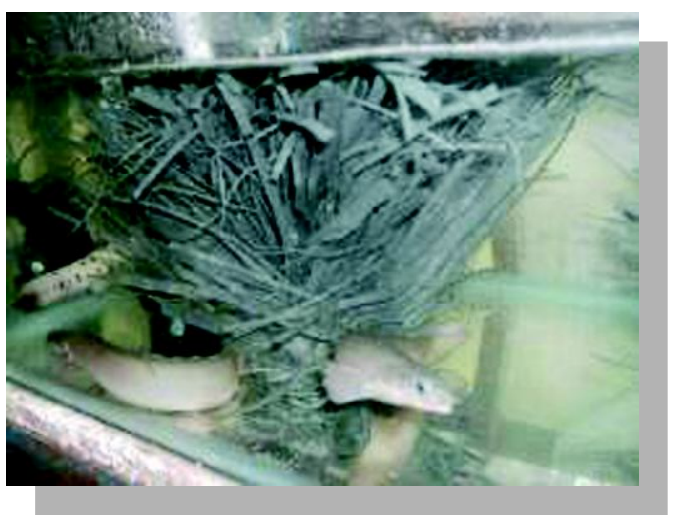

Gambar 4. Sarang buatan untuk pemijahan ikan Polypterus yang terbuat dari tali rafia (foto@Nugraha, 2009)

pembelahan sel palmas sangat sempurna mencirikan hewan ini masih primitiv (Subamia et al., 2008).

Perkembangan ontogeni Polypterus sangat unikfenomenal, saat fase burayak, overculum eksternal umumnya ditumbuhi sirip lunak, kemungkinan besar diduga adalah fase awal perkembangan insang yang melewati overculum, dalam kondisi ini, burayak Polypterus sangat rentan dengan predasi. Penonjolan sirip lunak tersebut juga ditemukan pada ikan Salamander, anehnya, sirip tersebut tereduksi seiring dengan laju-intergresi ontogenitif menuju dewasa.

Pengelolaan burayak Polypterus tidak terlalu susah, larva dapat ditransfer ke wadah yang lebih kecil untuk mempermudah pengontrolan (kesehatan larva, kualitas air, kontrol pakan, dan pemberiannya). Kuning telur larva mulai terlihat mengecil pada umur 7 hari, pada fase ini kita dapat memberikan pakan tambahan berupa M oina sp. Pada umur 20 hari, larva-larva sudah dapat diberikan pakan Artemia dan jentik Culex sp. Seiring dengan waktu 


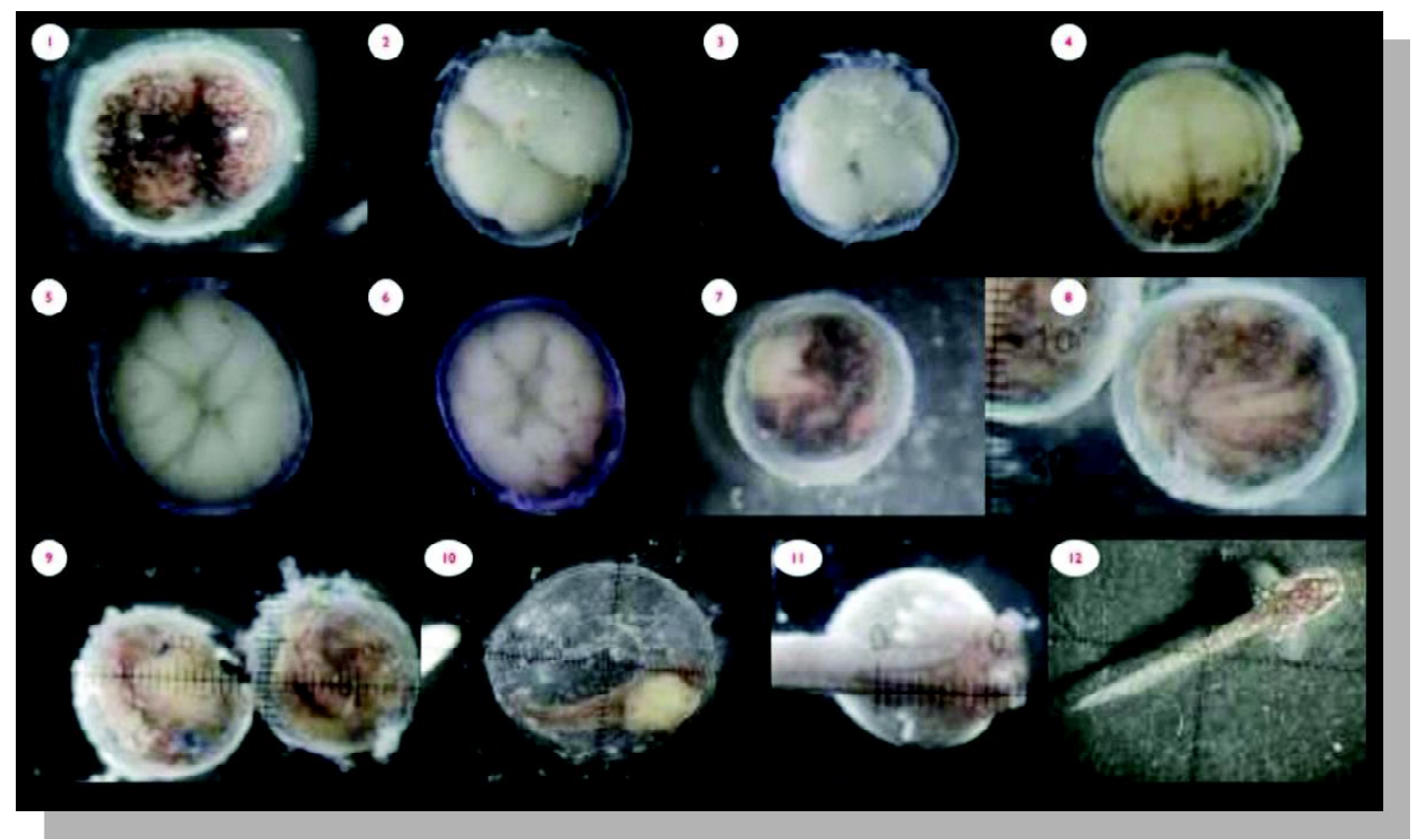

Keterangan:

1) Sel membelah menjadi dua, 2) sel membelah menjadi empat, 3) sel membelah menjadi delapan, 4) pembelahan sel (dilihat dari samping), 5) rongga blastula mulai terbentuk (blastula awal), 6) blastula, 7) kutub putih mulai mengecil, 8) diferensiasi sempurna bagian putih sudah tertutupi pembentukan embrio dimulai, 9) embrio awal, 10) embrio siap menetas, 11) terbentuk sirip ikan pada hari ketiga setelah menetas, 12) larva umur 7 hari

Gambar 5. Kompilasi perkembangan embrio Polypterus (Subamia et al., 2008)

hingga yuwana, Polypterus dapat diberikan cacing darah, cacing tanah, keong mas, dan atau ikan teri yang dicacah. Balai Riset Budidaya Ikan Hias, Depok, telah berhasil memijahkan Polypterus asal Senegal pada medio 2008 dan 2009. Subamia et al. (2008) melaporkan bahwa pada umur 10 bulan, gonad jantan dan betina sudah terbentuk sempurna, yang mengindikasikan bahwa ikan ini termasuk dalam takson ikan yang cepat dewasa.

\section{PROSPEKTIF IKAN HIAS DAN KONSERVASI}

Polypterus sudah dapat dibudidayakan dengan mudah di seluruh dunia, spesies-spesies ternama "bichir" sudah menjadi penghias akuarium Eropa dan Amerika hampir setengah abad. Mulai diminati oleh penggemar Asia, sejak 1985 hingga akhirnya menyebar ke penjuru Asia Tenggara.

Selain mudah dibudidayakan, ikan ini terjual laris dalam rekor penjualan yang stabil dengan harga beragam antara US\$ 40-US\$ 70 per ekor. Tingginya minat para penggemar ikan hias di belahan dunia terhadap ikan purba Polypterus, mengindikasikan bahwa manusia modern telah mewarisi spesies prasejarah yang membutuhkan ekstensifikasi dan konservasi exsitu untuk satu tujuan "menghindari terjadinya kepunahan".

\section{PENUTUP}

Mengenal lebih jauh fosil hidup Polypterus dan membudidayakannya, berarti kita telah mencintai spesies planet yang jauh lebih tua dari takson Teleostei lainnya. Warisan dunia ini membutuhkan ekspansi budidaya untuk mencegah dari bahaya kepunahan. Budidaya Polypterus telah memberikan warna tersendiri bagi corak diversitas spesies ikan hias Indonesia.

\section{DAFTAR ACUAN}

Babiker, M.M. 1984. Development of dependence on aerial respiration in Polyperus senegalus (Cuvier). Hidrobiologi. Springer Netherland. 110(1): 351-363.

Britz, R. 2004. Polypterus teugelsi, a new species of bichir from the Upper Cross River system in Cameroon (Actinopterygii: Cladistia: Polypteridae). Ichthyological Explorations of Freshwaters, 15: 179-186.

Brunet, M.M.P.F.T. 2000. Chad: discovery of a vertebrate fauna close to the Mio-Pliocene boundary. J. of Vertebrate Paleontology, 20:205-209.

Fessy, M.H. 1998. 1830, another revolution: The "quarrel of the analogues", 20(3): 149-151. 
Gallo, J. 2004. Senegal (Cuvier's) Bichir. http:// www.aquariumadvice.com.

Gillispie, C.C. 1989. Scientific Aspects of the French Egyptian Expedition 1798-1801. Proceedings of the American Philosophical Society, 13(4).

Gosse, J-P. 1990. Polypteridae. In: Leveque, C., Paugy, D., Teugels, G.G. (Eds.) Faune des poissons d'eaux douces et saumatres d'Afrique de I'Ouest I. MRAC Orstom, Collection Faune Tropicale, p. 79-87.

Hanssens, M.M., Teugels, G.G., van den, T., \& Audenaerde, D.F.E. 1995. Suspecies in the Polypterus palmas complex (Brachiopterygii; Polypteridae) from West and Central Africa. Copeia, p. 694-705.

Holden, M.J. 1971. Significance of Sexual Dimorphism of the Anal Fin of Polypteridae. Nature, 232: 135-136.

Komagata, K., Suzuki, A., \& Kuwabara, R. 1993. Sexual dimorphism in the polypterid fishes, Polypterus senegalus and Calamoichthys calabaricus. Ichthyological Research, 34(4): 387-390.

Kodera, H. 1992. Selection, care, behavior Jurassic fishes. Neptune City, N.J., 144 pp.

Noack, K., Zardoya, R., \& Meyer, A. 1996. The complete mitochondrial DNA sequence of the bichir (Polypterus ornatipinnis), basal ray-finned fish: Ancient establishment of the consensus verte-brategeneorder. Genetics, 144: 1165-1180.

Otero, O., Likius, A., Vignaud, P., \& Brunet, M. 2006. A new polypterid fish: Polypterus faraou sp. nov. (Cladistia, Polypteridae) from the Late M iocene, TorosMenalla, Chad. Zoological J. of the Linnean Societ, 146: 227-237.

Patterson, C. 1982. Morphology and Interrelationships of Primitive Actinopterygian Fishes. American Zoologist, 22 pp.
Palomares, M.L.D., Samb, B., Diouf, T., Vakily, J.M., \& Pauly, D. 2003. Fish Biodiversity: Local Studies as Basis for Global Inferences. ACP-EU Fisheries Research Report No. 14.

Poully, M. 1993. Habitat ecomorphologie et structure des peuplements de poissons dans trois petit cours d'eau tropicaux de Guinee. Reu. Hydrobiol. Frop., 26(4): 313-32.

Reichard, M. 2008. Microhabitat use by fishes in the middle course of the River Gambia in the Niokolo Koba National Park, Senegal: a unique example of an undisturbed West African assemblage. J. of Fish Biology, 72: 1815-1824.

Roberts, T.R. 1975. Geographical distribution of African freshwater fishes. Zoological J. of the Linnean Society, 57:249-319.

Rocco, L., Costagliola, D., Alessandra, A., Morescalchi M.A., \& Stingo, V. 2004. A molecular approach to systematics of Polypteriformes among Osteichthyes. Italian J. of Zoology, 71(4): 347-351.

Subamia, I.W., Nugraha, M.F.I., \& Sugito, S. 2008. Embryonic developmental stages of Palmas Polypterus senegalus senegalus. Indonesian aquaculture J., p. 119124.

Suzuki, D., Brandley, W.C., \& Tokita, M. 2010. The mitochondrial phylogeny of an ancient lineage of rayfinned fishes (Polypteridae) with implications for the evolution of body elongation, pelvic fin loss, and craniofacial morphology in Osteichthyes. Evolutionary Biology, 10: 21

Smits, W., Orgeig, S., \& Daniels, C.B. 1994. Surfactant composition and function in lungs of air-breathing fishes. Am. J. Physiology, Regulatory, Integrative and Comparative Physiological, 266: R1309-R1313. 